\title{
VIII. Observations on the Mesembryanthema Barbata
}

\section{A.H. Haworth Esq. F.L.S.}

To cite this article: A.H. Haworth Esq. F.L.S. (1824) VIII. Observations on the Mesembryanthema Barbata, Philosophical Magazine Series 1, 64:315, 61-62, DOI: $10.1080 / 14786442408644552$

To link to this article: http://dx.doi.org/10.1080/14786442408644552

里 Published online: 29 Jul 2009.

Submit your article to this journal $\lceil\pi$

Џ Article views: 3

Q View related articles $\sqsubset$ 
VIII. Observations on the Mesembryanthema barbata. By A. H. Haworth, Esq. F.L.S. \& c.

To the Editors of the Philosophical Magazine and Journal. Gentlemen,

H A VING recently had occasion to reconsider the remarkable plants which compose the section Barbata of the extensive genus Mesembryanthemum, added one new species to the group, and detected an error in nomenclature respecting an old one; I send you hereunder an amended account of the whole section and its botanical characters; which, perhaps, may be acceptable to the next Number of your valuable Miscellany; and I remain, gentlemen,

Your very respectful correspondent,

Chelsea, July 20, 1824.

A. H. Haworth.

\section{Mesembryanthemum. Sectio Barbata.}

\section{Sectionis Characteres.}

Suffrutices 2-11-entales plusve, papulosi, foliis apice radiatim stellato-barbatis.

Specierum Characteres.

barbatum. M. (The bearded, bushy) erectum: ramulis ef-

1. fuso-decumbentibus, foliis remotiusculis patentibus apice sub-sex-radiatis, calycinis laciniis subæqualibus. Mesemb. barbatum, a, Linn. Sp.Pl. 691.-Dillen. Hort. Elth. fig. 234. Bot. Mag. t. 70. M. stelligerum. Nob. in Synops. Succ. pl. \&c.

Obs. Finding this plant, communicated to me by Professor Williams, from the Botanic Garden of Oxford, to be the original $M$. barbatum of Linnæus; and at the same time being my $M$. stelligerum; I avail myself of this opportunity of rectifying the error, which may perhaps be the most appropriately done by the transposal of the names of the plants, as here adopted.

stclligerum. M. (The bearded, procumbent) ramis procum-

2. bentibus elongatis, foliis remotis semierectis apice subquinque-radiatis; calycinis laciniis præinæqualibus.Mesemb. barbatum. Nob. in Synops. Succ. exclusis synonymis.

Obs. Priore omnino debilior, sive procumbens, ramis longe paucioribus longioribus, foliis remotioribus magisque erectis. 
intonsum. M. (The black-bearded) ramulis erecto-decum-

3. bentibus effusis hirtulis, foliis apice sub-decen-radiatis; calyce barbâ nigrâ cincto.

Nova species, a Capite Bonæ Spei. Florebat in regio Horto Kewense, A.D. 1824, Julio mense.

Obs. Variat

a. rubicundum, floribus rubicundis, terminalibus solitariis.

B. album, floribus niveis nitentibus, morientibus pallidissime roseis.

Obs. Flores breviter pedunculati, pedunculis hispidis ebracteatis, setis albis erectis. Calyx 5-fidus turbinatus inferne hispidus, setis patentibus albis, tunc late barbâ validâ nigrâ cinctus, setis nigris subulatis expansis. Flores, A. M. ad solem ardentem solum expansi, post illos Mesem. barbati et minores. Folia in ramorum apices subconferta, semierecta plusve, pallidiora quam in prioribus et acutiora, basi sxpe incipienter ciliata; undique ad lentem papulis setulâ albâ adpressâ finientibus.

Distinguitur optimè hispidis ramulis, calycisve nigredine barbæ.

stellatum. M. (The small-bearded) foliis (ramulisque brevi-

4. bus grossis) cæespitosis canis crassis papuloso-scabris, apice multiradiatis, basi ciliatis; pedunculis calycibusque 6-8-fidis hirsutis.-M. stellatum. Pl. Grass. 29, cum icone.-Nob. in Revis. Pl. Succ. 191.

Rarius, et in sestu intenso solum floret.

densum. M. (The dwarf-bearded) densissime cæspitosum :

5. foliis papuloso-scabris, apice multiradiatis, basi subciliatis; pedunculis calycibusque 6-fidis hirsutissimis, caudice senili præcrasso ramuloso brevissimo. M.densum. Nob. in Synops. Succ.\&c.-Bot. Mag.t. 1220.

Obs. Flores rarissimi: æstu intenso solum vidi, quoque solum bis.

\section{Notices respecting Nere Books.}

THE First Part of the Philosophical Transactions of the Royal Society for 1824 has just appeared, and the following are its contents :

The Croonian Lecture. On the internal Structure of the Human Brain, when examined in the Microscope, as compared with that of Fishes, Insects and Worms. BySir Everard Home, Bart. V.P.R.S. - Some Observations on the Migra- 